\title{
Effect of Shade Levels on Leaf Area and Biomass Production of Three Varieties of Dracaena sanderiana L. in the Dry Zone of Sri Lanka
}

\author{
S. Srikrishnah*, S.E. Peiris ${ }^{1}$ and S. Sutharsan ${ }^{2}$ \\ Postgraduate Institute of Agriculture \\ University of Peradeniya \\ Sri Lanka
}

\begin{abstract}
An experiment was conducted in a shade house to determine the effects of three shade levels on leaf area and biomass production of three varieties of dracaena (Dracaena sanderiana L.) in the dry zone (Batticaloa district) of Sri Lanka. 'Gold', 'Victory' and 'White' varieties were arranged in $50 \%, 70 \%$ and $80 \%$ shade levels as a CRD. There was a significant interaction between varieties of dracaena and the shade levels on leaf area and biomass production. The plants grown at 50\% and $70 \%$ shade levels produced the highest leaf area and biomass than plants subjected to $80 \%$ shade. Biomass production was in accordance with the trend of variances for leaf area. Varieties 'Gold' and 'Victory' performed better than 'White' in leaf area and biomass production under $50 \%$ and $70 \%$ shade level and there were no significant variations between them. Therefore, in this study it was concluded that, $70 \%$ shade level is suitable for growing dracaena varieties in the dry zone of Sri Lanka as the growth of dracaena varieties were higher than the other shade levels.
\end{abstract}

Key words: Biomass production, dracaena, dry zone, leaf area, shade levels

\section{INTRODUCTION}

Dracaena (Dracaena sanderiana L.) is a popular foliage plant (Beura et al., 2007) that belongs to family Dracaenaceae. It is commonly known as Ribbon Dracaena, Lucky Bamboo, Belgian Evergreen or sometimes Ribbon Plant. It consists of several varieties including 'Gold', 'Victory' and 'White'. Dracaena is an evergreen foliage plant grown as a house or outdoor plant and it has a high demand in the export market. Dracaena varieties are commercially produced in export-oriented large scale plantations in Sri Lanka (Senevirathne et al., 2007). In 2010, export earnings from cut flowers and foliage were US \$ 11.71 million (Anon, 2010). The potential exists for increased exports of cut foliages and rooted cuttings.

The agro-climatic diversity in Sri Lanka is very much advantageous for growing a wide range of foliage ornamentals and cut flowers. But commercial production facilities of floriculture products are mainly found in the central uplands and the lowlands in western and north-western regions (Weerakkody, 2004).

When expanding floriculture as an industry in Sri Lanka, it is essential to identify new niches for cultivation. Dry zone which comprises more than $2 / 3$ of land area in Sri Lanka has

Department of Crop Science, Faculty of Agriculture, University of Peradeniya, Peradeniya, Sri Lanka

Department of Crop Science, Faculty of Agriculture, Eastern University, Vantharumoolai, Sri Lanka

Author for correspondence: shansri7@gmail.com 
several potentials for future agricultural development. Climatic conditions prevailing in the dry zone are suitable for growing tropical flowers and foliage ornamentals under appropriate conditions. Introduction of floricultural crops in the dry zone could be an important intervention in this regard, where the farmers can earn more using available natural resources efficiently. These crops fetch better prices almost year round and there is no need to wait for a long time as in the case of conventional crops.

Batticaloa is a prominent agricultural district in the dry zone of Sri Lanka. The topography of the Batticaloa district is flat. The east coast of the district comprises of sandy soil and the west comprises of clay soil. The annual rainfall varies from $864 \mathrm{~mm}$ to $3081 \mathrm{~mm}$ distribution, which has slight variation throughout the district. The temperature ranges from $25{ }^{\circ} \mathrm{C}$ to $35.4{ }^{\circ} \mathrm{C}$ (Anon, 2004). Introduction of floricultural crops in Batticaloa district as a commercial venture would furnish several benefits to society. It could act as a livelihood activity for many women-headed households. Growth of this sector would contribute to the national economy through earning of foreign exchange.

However, researches on floricultural crops have not been conducted yet in an organized manner in the dry zone. An important ecological factor to be considered to any cultivated species is the best irradiance level (Mattana et al., 2006). Shade levels influence the growth and quality of ornamentals plants and provision of shade is recommended for the cultivation of foliage plants in Sri Lanka. Netting is an effective solution for ornamentals, which enhance their quality (Shahak et al., 2008). A better understanding of possible influence of different shade levels on the growth, development and quality of dracaena could lead to development of recommendation for the agronomic management of different cultivars of dracaena in the dry zone of Sri Lanka.

The leaf area of a crop is a determining factor in mechanisms such as radiation interception and water and energy exchange (Peksen, 2007). Plant biomass and productivity are interrelated (Guo, 2007), which influence the growth and development of a crop. The objectives of this research was to determine the effect of three shade levels on the leaf area and biomass production of three varieties of dracaena and to select the best shade level for their cultivation in the Batticaloa district.

\section{MATERIALS AND METHODS}

A shade house experiment was conducted from December 2010 to May 2011 at the Crop farm, Eastern University, Vantharumoolai, Batticaloa. Uniform, rooted and one month old cuttings of three varieties of dracaena 'Gold', 'Victory' and 'White' were obtained from conventional propagation techniques and planted in polybags $(15 \mathrm{~cm}$ diameter and $20 \mathrm{~cm}$ height) filled with a potting medium consisting of loam soil, compost, cattle manure, sand in a ratio of 4:2:1:1 (volume basis). A basal fertilizer consisting of urea $(87 \mathrm{~kg})$, muriate of potash $(67 \mathrm{~kg})$ and super phosphate $(89 \mathrm{~kg})$ were mixed thoroughly and $9 \mathrm{~g}$ of mixture was applied per bag (Department of Agriculture, 2002). A liquid fertilizer (Crop Master ${ }^{\mathbb{B}}$ Unipower) application was practiced once a month to all treatments equally. Plants were arranged at a spacing of 30 plants $/ \mathrm{m}^{2}$. Experimental plants were watered according to the shade levels. Plants at $50 \%$ and $70 \%$ shade levels were watered once in 3 days and plants at $80 \%$ shade were watered once in 5 days during dry periods. Other management practices were followed uniformly. 
The treatments were arranged in a completely randomized design (CRD) with 3 replicates. Each replication contained 30 plants and an experimental unit consisted of one plant. The three varieties of dracaena ('Gold', 'Victory' and 'White') and additive series of shade levels $(50 \%, 70 \%$ and $80 \%)$ were arranged in a two factor factorial design. The crop was grown for six months.

The leaf area $\left(\mathrm{cm}^{2}\right)$ and biomass production $(\mathrm{g})$ were taken as measurements. Analysis of variance was carried out using SAS package to determine significant differences among treatments $(\mathrm{p}<0.05)$. Regression analysis was used to characterize the effects of shade levels on leaf area and biomass production of the three varieties.

\section{RESULTS AND DISCUSSION}

The study showed significant differences $(\mathrm{p}<0.05)$ between treatments tested (Table 1$)$.

Table 1. Effect of shade levels on leaf area and biomass production of three varieties of dracaena at $5^{\text {th }}$ month after planting

\begin{tabular}{cccc}
\hline $\begin{array}{c}\text { Shade level } \\
(\mathbf{\%})\end{array}$ & Variety & $\begin{array}{c}\text { Leaf area } \\
\left(\mathbf{c m}^{\mathbf{2}}\right)\end{array}$ & $\begin{array}{c}\text { Biomass production } \\
\mathbf{( g )}\end{array}$ \\
\hline 50 & Gold & $897.33^{\mathrm{a}}$ & $14.77^{\mathrm{a}}$ \\
& Victory & $911.67^{\mathrm{a}}$ & $14.83^{\mathrm{a}}$ \\
70 & White & $744.67^{\mathrm{b}}$ & $9.94^{\mathrm{b}}$ \\
& Gold & $924.00^{\mathrm{a}}$ & $14.51^{\mathrm{a}}$ \\
& Victory & $901.00^{\mathrm{b}}$ & $14.22^{\mathrm{a}}$ \\
80 & White & $607.33^{\mathrm{c}}$ & $10.24^{\mathrm{b}}$ \\
& Gold & $303.00^{\mathrm{b}}$ & $4.39^{\mathrm{a}}$ \\
& Victory & $344.67^{\mathrm{a}}$ & $4.17^{\mathrm{a}}$ \\
Probability & White & $287.67^{\mathrm{c}}$ & $3.89^{\mathrm{a}}$ \\
& Shade levels & 0.000 & 0.000 \\
& Varieties & 0.000 & 0.000 \\
$\mathrm{CV}$ & Interaction & 0.000 & 0.000 \\
\hline
\end{tabular}

Means followed by the same letter were not significant at $\mathrm{p}=0.05$

\section{Leaf area}

The varieties and shade levels had a significant effect $(\mathrm{p}<0.05)$ on leaf area (LA) of dracaena. The interactive effect of the varieties and shade levels on LA of dracaena was also significant (Table 1). The plants grown at 50 and $70 \%$ shade levels produced the highest LA than the plants of $80 \%$ shade. The growth of crops was related to the amount of solar radiation received during the growing period (Cockshull et al., 1992; Challa \& Bakker, 1998). LA is also influenced by shade levels. Abdel-Mawgoud et al. (1996) reported that30 \% of shade has a significant effect on LA of tomato. At $80 \%$ shade, development of LA was significantly reduced in all three dracaena varieties as radiation received by the plants was below the requirement. This may have caused reduction in photosynthesis and subsequent growth. Ultimately, the growth and leaf development of the plants were suppressed irrespective of the variety at $80 \%$ shade. Under this shade level, variety 'Victory' had a 
significantly $(\mathrm{p}<0.05)$ higher LA followed by 'Gold'. Lowest LA was shown by variety 'White'.

In the treatment of $50 \%$ shade, there were no significant $(p<0.05)$ differences between LA of varieties 'Gold' and 'Victory'. The variety 'White' produced a significantly lower LA than those of the other varieties. At $70 \%$ shade level, there was a significant difference between varieties in LA. The highest LA was produced by the variety 'Gold' followed by 'Victory'. The lowest LA was shown by the variety 'White'. In all three shade levels, the variety 'White' produced the lowest LA. These variations may be due to varietal effects on the LA. It was reported that the genotypic variations have significant effects on the LA (Sashidhar et al., 1986; Rebetzke et al., 2004). As such, varieties 'Gold' and 'Victory' performed better than the variety 'White' in leaf formation.

There were no significant differences in the LA of the varieties 'Gold' and 'Victory' at 50\% and $70 \%$ shade levels. At higher irradiation levels, there may be chances for destruction of photosynthetic pigments in sensitive plant leaves. Mattana et al. (2006) also reported that, higher irradiance levels in esciophyte plants, such as Pothomorphe umbellata, can cause photodegradation of chromopigments, with a decrease in photosynthesis causing in a decrease in the biomass yield. The degradation of the photosynthetic pigments probably was responsible for the decrease of photosynthesis and growth. It is probably due to the destruction of the photosynthetic pigments and the structures of thylakoids in chloroplasts (photodestruction) (Lambers et al., 1998). Leaves of dracaena might be sensitive to higher irradiation levels, which would have caused destruction of photosynthetic pigments and subsequent reduction of growth. This may be the reason for reduction of LA in dracaena under $50 \%$ shade level.

A 70\% shade level seemed to be preferable for the optimum growth of LA of varieties 'Gold' and 'Victory'. Very high light intensity, which exceeds photosynthetic capability of the plants, results in photoinhibition and pale foliage (Stancato et al., 2010). There were no symptoms of leaf burning or pale colouration in all three varieties under $70 \%$ shade level, which showed that $70 \%$ shade providing sufficient amount of light for optimum growth of the varieties 'Gold' and 'Victory'. This could be the possible reason for the approximately equal LA of dracaena varieties 'Gold' and 'Victory' under 50 and $70 \%$ shade levels.

\section{Biomass production}

Shade levels significantly $(\mathrm{p}<0.05)$ influenced biomass production of the three varieties of dracaena (Table 1). At $80 \%$ shade, all varieties produced the lowest biomass and their differences became non-significant. Of all the climatic factors, light plays a major role in determining productivity. Shading by 31 to $67 \%$ reduced root yield of sweet potato (Mwanga \& Zamora, 1989). LA of plants was also lower under $80 \%$ shade. Dry matter production decreases with a decrease of leaf area index (Dalirie et al., 2010). Hence, low irradiation and LA would have caused a reduction in photosynthesis and, thereby dry matter accumulation under $80 \%$ shade level.

At $50 \%$ shade, a significantly ( $\mathrm{p}<0.05$ ) highest biomass was produced by varieties 'Victory' and 'Gold', while lowest was produced by the variety 'White'. The same phenomenon was observed at $70 \%$ shade. Under both 50 and $70 \%$ shade levels, there was no significant $(\mathrm{p}<0.05)$ difference between biomass production of varieties 'Gold' and 'Victory'. Varieties 'Gold' and 'Victory' produced the highest LA and thereby would have captured more solar radiation under 50 and $70 \%$ shade levels which contribute to photosynthesis and biomass 
production. Dalirie et al. (2010) stated that, increasing LA index as one of the ways of increasing the capture of solar radiation within the canopy and production of dry matter. In this experiment, it could be stated that, biomass production were in accordance with the trend of variances for LA. Varieties 'Gold' and 'Victory' performed better under 50 and $70 \%$ shade levels in terms of biomass production.

\section{Rate of increase of leaf area versus time}

With time, leaf area of dracaena increased linearly under the three shade levels (Figs. 1, 2 \& 3 ), but there were prominent variations in the rate of development.

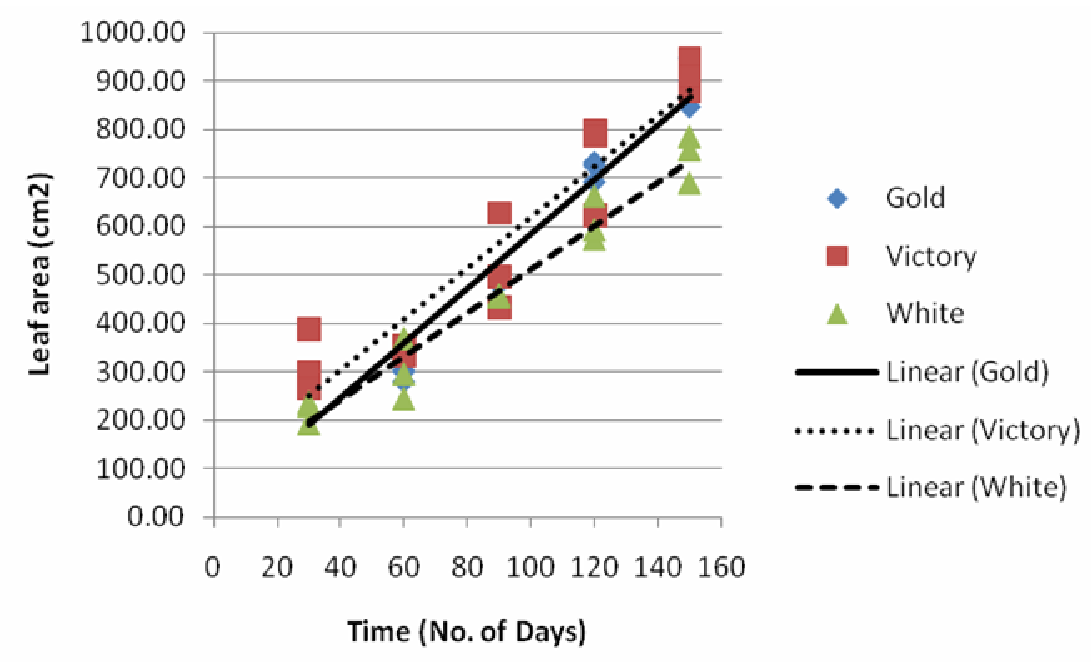

Fig. 1. Growth rate in leaf area at $50 \%$ shade level during experimental period

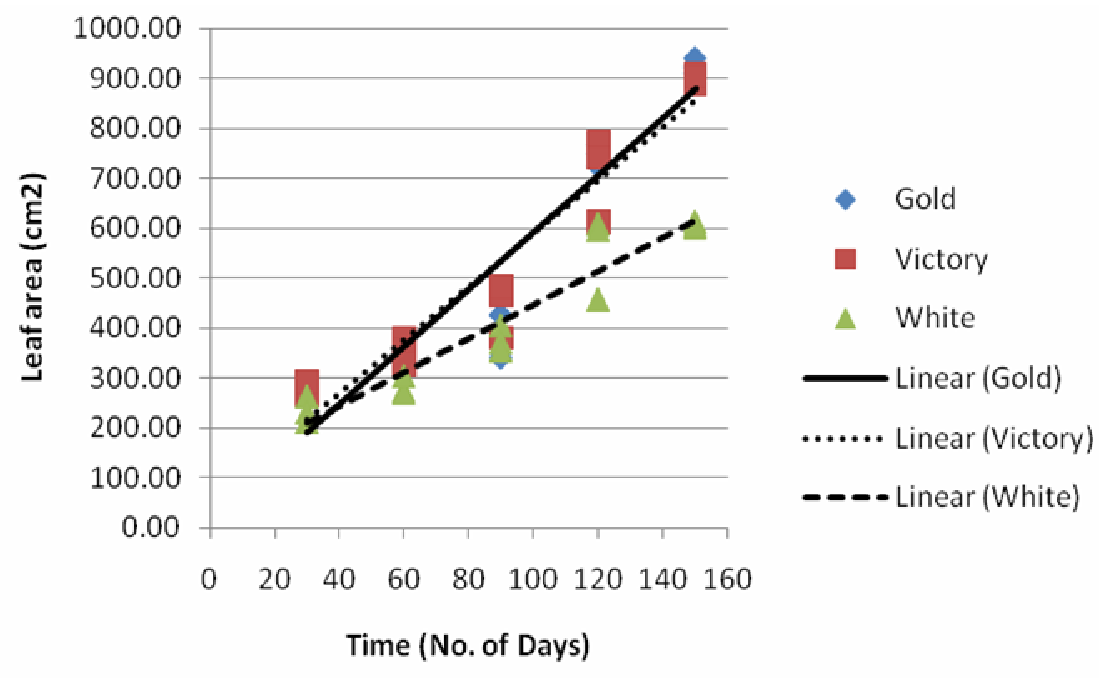

Fig. 2. Growth rate in leaf area at $70 \%$ shade level during experimental period 


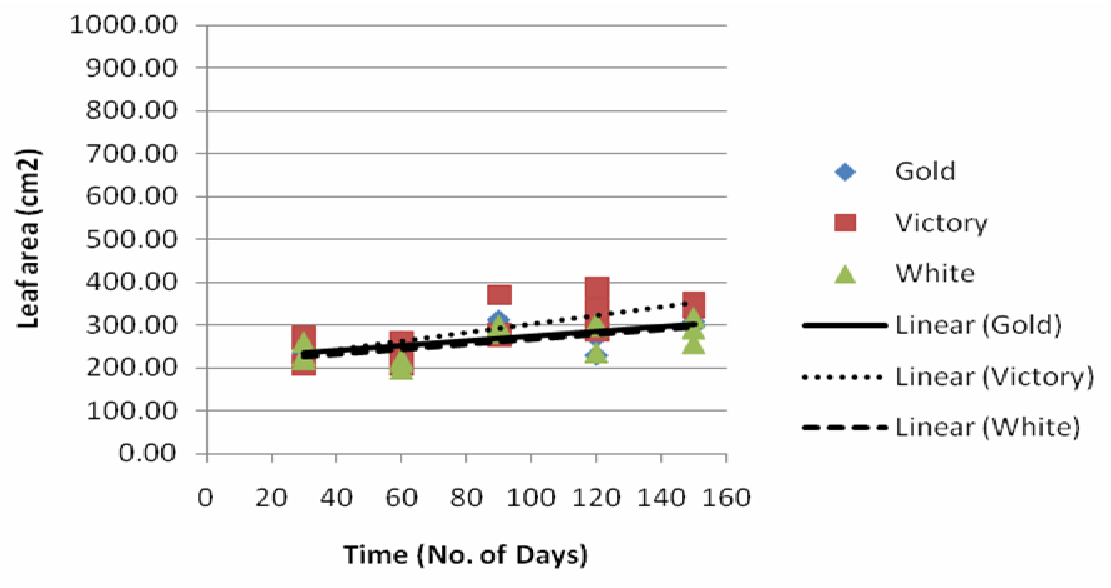

\section{Fig. 3. Growth rate in leaf area at $80 \%$ shade level during experimental period}

The LA development was higher at 50 and $70 \%$ shade levels than at $80 \%$ shade, as evidenced by higher gradients of the regression equations (Table 2). Higher shade levels could reduce the photosynthesis and growth of plants. Halva et al. (1992) reported that, the cultivation of Anethum graveolens under four levels of brightness, 100\%, 70\%, 50\% and $30 \%$ showed that the decrease in levels of brightness resulted in a decrease of the number of leaves and specific LA. The same was observed in the present study that, LA development was lower under $80 \%$ shade level (Table 1).

Table 2. The relationship between shade and variety on LA

\begin{tabular}{cllcc}
\hline Shade Level (\%) & Variety & Prediction equation & $\mathbf{R}^{2}$ & p value \\
\hline 50 & Gold & $\mathrm{y}=5.6133 \mathrm{x}+23.667$ & 0.9431 & $<0.05$ \\
& Victory & $\mathrm{y}=5.2622 \mathrm{x}+92.2$ & 0.8983 & $<0.05$ \\
& White & $\mathrm{y}=4.5178 \mathrm{x}+60.4$ & 0.9602 & $<0.05$ \\
70 & Gold & $\mathrm{y}=5.7367 \mathrm{x}+18.833$ & 0.9071 & $<0.05$ \\
& Victory & $\mathrm{y}=5.3467 \mathrm{x}+55.4$ & 0.9200 & $<0.05$ \\
& White & $\mathrm{y}=3.3778 \mathrm{x}+108.07$ & 0.9091 & $<0.05$ \\
80 & Gold & $\mathrm{y}=0.5567 \mathrm{x}+219.43$ & 0.4609 & $<0.05$ \\
& Victory & $\mathrm{y}=1.0022 \mathrm{x}+203.07$ & 0.5560 & $<0.05$ \\
& White & $\mathrm{y}=0.5711 \mathrm{x}+209.27$ & 0.4123 & $<0.05$ \\
\hline
\end{tabular}

The growth rate of LA of varieties 'Gold' and 'Victory' was higher than that of variety 'White' at 50 and $70 \%$ shade levels. This may be due to varietal effects on LA. The rate of development of LA of varieties 'Gold' and 'Victory' were approximately similar at shade levels 50 and $70 \%$. The treatments 50 and $70 \%$ of shade levels were better than $80 \%$ level for growth of dracaena varieties in the dry zone of Sri Lanka in terms of LA development.

\section{Rate of increase of biomass production versus time}

Biomass of dracaena varieties increased with the time under different shade levels. A linear relationship clearly represents the differences of varieties on biomass production under different shade levels (Figs. 4, 5, \& 6). However, the rate of biomass production of different varieties differed notably with shade levels. 


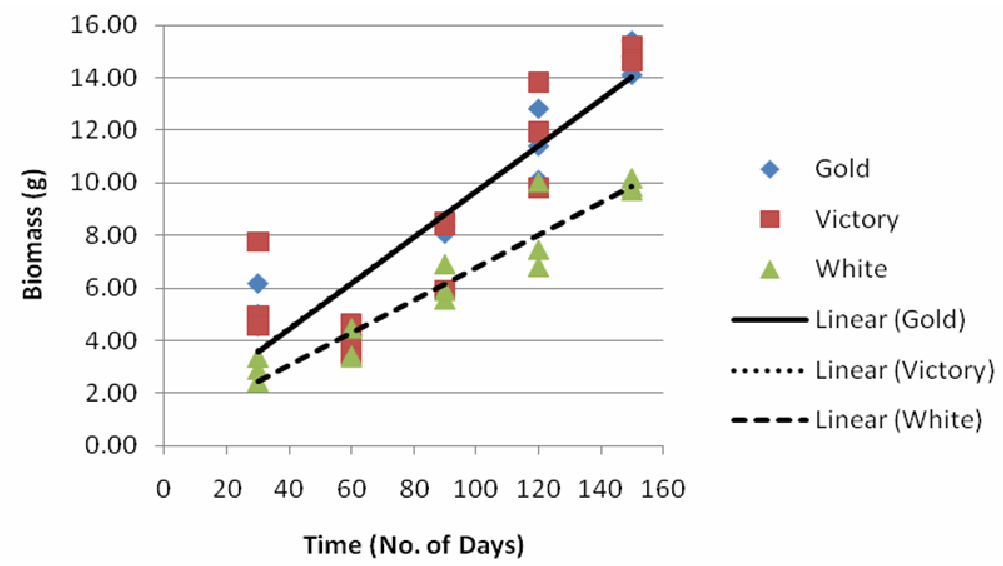

Fig. 4. Growth rate in biomass at $50 \%$ shade level during experimental period

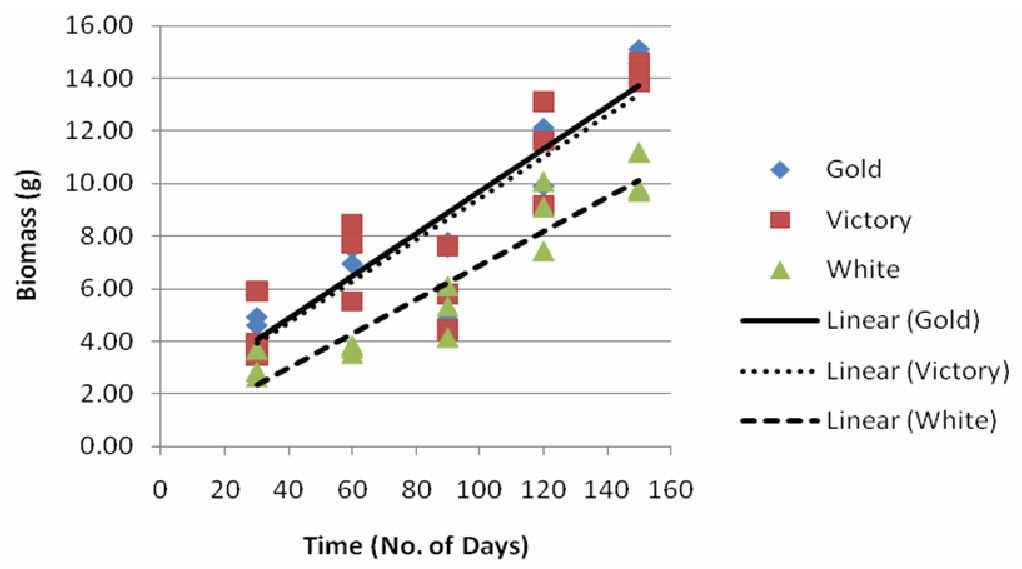

Fig. 5. Growth rate in biomass at $70 \%$ shade level during experimental period

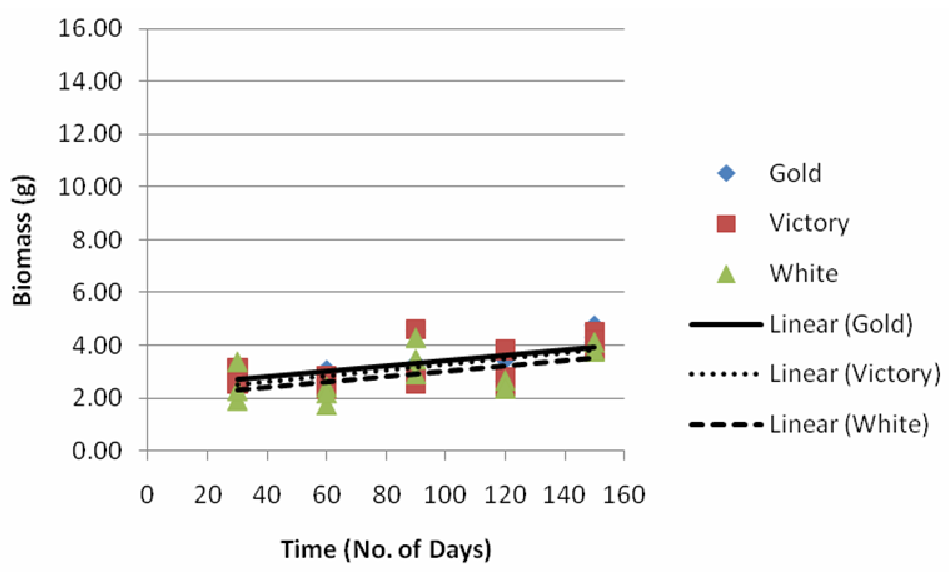

Fig. 6. Growth rate in biomass at $80 \%$ shade level during experimental period 
Biomass production of dracaena varieties was higher at 50 and $70 \%$ shade levels than $80 \%$ shade (Table 3). At high radiation levels, the rate of biomass production was higher. Shade reduces plant biomass production, and at 30\% shade, total dry matter production was significantly reduced in tomato (Abdel-Mawgoud et al., 1996). As such, biomass production was lower under $80 \%$ shade level.

Table 3. Relationship between shade and varieties on biomass production at $\mathbf{p}<0.05$

\begin{tabular}{cllc}
\hline Shade Level \% & Variety & Prediction equation & $\mathbf{R}^{\mathbf{2}}$ \\
\hline 50 & Gold & $\mathrm{y}=0.0874 \mathrm{x}+0.9303$ & 0.8815 \\
& Victory & $\mathrm{y}=0.0865 \mathrm{x}+1.0433$ & 0.7909 \\
& White & $\mathrm{y}=0.0616 \mathrm{x}+0.621$ & 0.9134 \\
70 & Gold & $\mathrm{y}=0.0802 \mathrm{x}+1.689$ & 0.8456 \\
& Victory & $\mathrm{y}=0.0788 \mathrm{x}+1.5337$ & 0.7744 \\
& White & $\mathrm{y}=0.065 \mathrm{x}+0.371$ & 0.8845 \\
80 & Gold & $\mathrm{y}=0.0103 \mathrm{x}+2.3957$ & 0.373 \\
& Victory & $\mathrm{y}=0.0106 \mathrm{x}+2.2147$ & 0.3439 \\
& White & $\mathrm{y}=0.0103 \mathrm{x}+1.986$ & 0.3026 \\
\hline
\end{tabular}

The biomass production rate of varieties 'Gold' and 'Victory' were higher than that of variety 'White' at 50 and 70\% shade level. Variety 'White' had low leaf area development rate (Table 2). The decrease of the photosynthesis activity may have related to the decrease in dry matter accumulation. Guttieri et al. (2001) reported that dry matter accumulation decreased due to decrease in leaf number, leaf area index and acceleration in leaf senescence. The biomass production rate of varieties 'Gold' and 'Victory' were approximately similar at shade levels of 50 and $70 \%$. There is a high positive correlation between LA and biomass production and the biomass production followed to a similar pattern to that LA development (Table 2). Fifty percent and $70 \%$ shades were better than $80 \%$ shade for the growth of dracaena varieties in the dry zone of Sri Lanka with regard to biomass production.

\section{CONCLUSIONS}

The dracaena varieties used in this study performed better under 50 and $70 \%$ shade levels. The varieties 'Gold' and 'Victory', with little differences, attained a high LA and dry matter levels. Further, growth rates of varieties were higher at 50 and $70 \%$ shade levels than at $80 \%$ shade level. It could be concluded that, $70 \%$ shade level is suitable for growing dracaena varieties in the Batticaloa district of Sri Lanka and the varieties 'Gold' and 'Victory' are most suitable than the variety 'White'.

\section{REFERENCES}

Abdel-Mawgoud, A.M.R., El-Abd, S.O., Singer, S.M., Abou-Hadid, A.F. and Hsiao, T.C. (1996). Effect of shade on the growth and yield of tomato plants. Acta Hort. 434, 313-320.

Anon. (2004). District Profile: Batticaloa. Consortium of Humanitarian Agencies [on line]. [Accessed on 25.12.2010]. Available at http://www.humanitariansrilanka.org/eResources/PDFdocs/District_Profile/distict6.pdf 
Anon. (2010). Summary of Export Performance 2008, 2009 and 2010. Export Development Board, Sri Lanka [on line]. [Accessed on 25.05.2011]. Available at http://www.srilankabusiness.com/eresearch/pdf files/summary $\% 20$ of $\% 20$ export $\% 20$ perform ance $\% 202008, \% 202009 \% 20 \& \% 202010 \% 20$.pdf

Beura, S., Samal, P. and Jagadev, P.N. (2007). Preliminary studies of in vitro cloning of Dracaena (Dracaena sanderiana). Acta Hort. 760, 241-246.

Challa, H. and Bakker, J. (1998). Potential production within the greenhouse environment. pp. 333-348. In: Enoch, Z. and Stanhill, G. (Ed.) Ecosystems of the world. The greenhouse ecosystem. Elsevier., Amsterdan, Netherlands.

Cockshull, K.E., Graves, C.J. and Cave, C.R.J. (1992). The influence of shading on yield of glasshouse tomatoes. J. Hort. Sci. 67, 11-24.

Dalirie, M.S., Sharifi, R.F. and Farzaneh, S. (2010). Evaluation of yield, dry matter accumulation and leaf area index in wheat genotypes as affected by terminal drought stress. Notulae Botanicae Horti Agrobotanici Cluj-Napoca. 38(1), 182-186.

Department of Agriculture of Sri Lanka. (2002). Foliage plants and other ornamentals [on line]. [Accessed on 25.10.2010]. Available at http://www.agridept.gov.lk.Techinformations/flindex.htm

Guo, Q. (2007). The diversity-biomass-productivity relationships in grassland management and restoration. Basic and Appl. Ecol. 8, 199-208.

Guttieri, M.J., Stark, J.C., Obrien, K. and Souza, E. (2001). Relative sensitivity of spring wheat grain yield and quality parameters to moisture deficit. J. Crop Sci. 41, 327-335.

Halva, S., Craker, L.E., Simon, J.E. and Charles, D.J. (1992). Light levels, growth, and essential oil in dill (Anethum graveolens L.). J. Herbs Spices Med. Plants. 1(1), 47-58.

Lambers, H., Chapin III, F.S. and Pons, T.L. (1998). Plant Physiological Ecology. SpringerVerlag, New York, USA, p. 540.

Mattana, R.S., Ming, L.C., Marchese, J. A. and Marques, M.O.M. (2006). Biomass production in plants of Pothomorphe umbellata (L.) Miq. submitted to different shade levels. Braz. J. Med. Biol. Res. 8, 83-85.

Mwanga, R.O.M. and Zamora, O.B. (1989). Response of sweet potato (Ipomoea batatas (L.) Lam) to varying levels of shade: I. Yield and yield components. Phillip. J. Crop Sci. 13(3), 133-139.

Peksen, E. (2007). Non-destructive leaf area estimation model for faba bean (Vicia faba L.) Sci. Hortic., 113, 322-328.

Rebetzke, G.J., Botwright, T.L., Moore, C.S., Richards, R.A. and Condon. A.G. (2004). Genotypic variation in specific leaf area for genetic improvement of early vigour in wheat. Field Crops Res. 88, 179-189. 
Sashidhar, V.R., Gurumurthy, B.R., Prasad, T.G., Udaya Kumar, M., Seetharam A. and Krishna Sastry, K.S. (1986). Genotypic variation in carbon exchange rate, functional leaf area and productivity in finger millet (Eleusine coracana gaertn.): An approach to identify desirable plant types for higher water use efficiency under rainfed conditions. Field Crops Res. $\underline{13}, 133-146$.

Senevirathne, G.A.S.S., Kumari, D.L.C. and Disanayake, L. (2007). Productivity improvement of foliage plant Dracaena sanderiana (Ribbon Dracaena) variety "White". Proc. Sri Lanka Assoc. of Advan. Sci. 63(1), 186.

Shahak, Y., Ratner, K., Giller, Y.E., Zur, N., Or, E., Gussakovsky, E.E., Stern, R., Sarig, P., Raban, E., Harcavi, E., Doron, I. and Greenblat-Avron, Y. (2008). Improving solar energy utilization, productivity and fruit quality in orchards and vineyards by photoselective netting. Acta Hort. 772, 65-72.

Stancato, G.C., Mazzafera, P. and Buckeridge, M.S. (2002). Effects of light stress on the growth of the epiphytic orchid Cattleya forbesii Lindl. X Laelia tenebrosa Rolfe. Revista Brasil. Bot. 25(2), 229-235.

Weerakkody, W.A.P. (2004). Horticulture in Sri Lanka, Chronica Hort. 44, 23-27. 